\title{
Epäterveellisten ruokailutottumusten syytä ei kannata etsiä tyhmyydestä
}

Lihavuudesta ja epäterveellisistä ruokailutottumuksista on kannettu huolta jo vuosikymmeniä. 1950- ja -60-luvun kirjallisuudessa lihavuus typistyy lähinnä ravintofysiologiseksi ongelmaksi, joka ratkeaa yksinkertaisesti syömällä kulutusta vähemmän. Kuitenkin jo tuolloin uumoiltiin, että epäterveellisiin ruokailutottumuksiin vaikuttaa fysiologian lisäksi myös psyykkisiä tekijöitä, jotka voivat häiritä ruokahalun ravinnonottoa säätelevää toimintaa. Professori Martti J Mustakallio osasikin jo 60 vuotta sitten pohtia ruokailutottumuksia käyttäytymistieteellisemmästä näkökulmasta. Hän nimittäin kirjoitti Lihavuuden Vastustamisyhdistys ry:n kirjasessa "Kuta pitempi vyö - sitä lyhempi elämä: Ajattelemisen aihetta ja neuvoja liikapainoisille" seuraavasti: "yli $90 \%$ :ssa kaikista tapauksista lihavuus aiheutuu yksinomaan tyhmyydestämme. [...] Mutta tässä meillä on myös erinomainen tilaisuus lykätä syy toisten niskoille, nimittäin rakastavien äitien ja hellien aviovaimojen. Monet meistä ovat näet oppineet huonot ruokatapansa eli liiallisen syömisen jo lapsena, kun äiti on tunkenut ruokaa niin paljon kuin lapsen mahalaukku ikinä vetää. Näin tämä pussi on venynyt ja tottunut saamaan paljon.
Kun sitten vielä rakastava aviovaimo jatkaa tätä syöttöä, jotta mies "voisi hyvin", [...] on kohtalomme selvä ja ennenaikainen hauta häämöttää edessämme.”

Nykyinen terveys- ja ravitsemuskeskustelu on onneksi monimuotoisempaa, ja elintapoihin liittyviä tekijöitä tunnetaan laajasti. Tällä hetkellä julkisessa keskustelussa on vallalla yksilöllisyyttä korostava trendi, jossa yksilö on toisaalta vapaa tekemään itseään ja terveyttään koskevia päätöksiä, mutta toisaalta myös vastuussa näistä päätöksistä ja niiden seurauksista. Kesäkuun alussa julkaistun e2-ajatuspajan raportin mukaan yli $80 \%$ vastaajista arvioi, etteivät suomalaiset ota tarpeeksi vastuuta omasta terveydestään. Väestön terveyserojen koetaan johtuvan kansalaisten omista yksilöllisistä valinnoista, ei sosioekonomisista lähtökohdista, vaikka tutkimusnäyttö puhuu päinvastaista. Enemmistö vastaajista oli myös sitä mieltä, että jokaisen pitäisi kantaa enemmän vastuuta omasta hyvinvoinnistaan. Erityisesti ruokavalio, liikunta, alkoholinkäyttö ja tupakointi - elintavat, jotka liittyvät kroonisiin sairauksiin - nähdään yksilön omina valintoina, jolloin ihminen on itse vastuussa sairauksistaan. Tämä vapaus ja vastuu -retoriikka kui- tenkin jättää huomioimatta sen tosiasian, että yksilö ei koskaan tee valintojaan tyhjiössä.

On selvää, että yksilön ominaisuudet - esimerkiksi perimä ja muut biologiset tekijät, kuten sukupuoli ja ikä - vaikuttavat hänen terveyskäyttäytymiseensä. Samoin yksilön asenteilla ja hänen hankkimillaan tiedoilla ja taidoilla on merkitystä. Samaan aikaan valintoihin vaikuttaa kuitenkin myös se ympäristö, jossa yksilö valintojaan tekee. Monesti tätä ympäristöä kuvataan niin sanotun sosio-ekologisen mallin avulla, jossa yksilöä ajatellaan ympäröivän yhtäältä sosiaalinen ja toisaalta fyysinen ympäristö. Olemme alttiita sosiaaliselle paineelle, jonka vaikutukset voivat olla sekä terveyttä edistäviä että täysin päinvastaisia: ystävän esimerkki voi saada vetämään lenkkarit jalkaan entistä useammin tai toisaalta kaveripiiri voi kannustaa vaikkapa päihteiden käyttöön. Tiedetään myös, että fyysisellä, rakennetulla ympäristöllä on oma merkityksensä. Klassinen esimerkki on hissin ja portaiden sijoittelu julkisissa rakennuksissa: usein hissi on näkyvällä paikalla heti sisääntuloaulan lähettyvillä, kun taas portaat on piilotettu rappukäytävään suljettujen ovien taakse. On helppo arvata, että suurin osa 
valitsee hissin. Kaiken tämän lisäksi terveyskäyttäytymiseen vaikuttavat myös yhteiskunnan rakenteet. Esimerkiksi maankäytön suunnittelu vaikuttaa siihen, kuinka houkuttelevaa työmatkapyöräily on. Lisäksi verotuksella tai tukiaisilla voidaan ohjata käyttäytymistä sekä yksilön tasolla että laajemminkin. Iso-Britanniassa otettiin tänä vuonna käyttöön virvoitusjuomavero, jonka suuruus riippuu juoman sokeripitoisuudesta. On luultavaa, että kohtuullisen pienellä verolla ei ole kovin suurta vaikutusta yksilön ostopäätökseen. Merkittävämpää onkin todennäköisesti se, että asteittainen sokeripitoisuudesta riippuva vero sai tuottajat muokkaamaan reseptejään vähemmän sokeripitoisiksi veron pienentämiseksi.

Kun puhutaan ympäristön vaikutuksesta ruoankäyttöön ja ravitsemukseen, puhutaan ruokaympäristöstä. Sillä tarkoitetaan kaikkea, mikä voi vaikuttaa ruoankäyttöön: esimerkiksi fyysistä, sosiaalista, kulttuurista, taloudellista tai poliittista ympäristöä. Ruokaympäristön merkitys korostuu entisestään silloin, kun kyseessä on väestöryhmä, joka ei itse tee kaikkia ruokaan liittyviä valintojaan - esimerkiksi lapset tai vaikkapa laitoshoidossa olevat ikääntyneet. Lapset ja perheet ovat usein terveys- ja ravitsemustutkimuksen fokuksessa, koska lapsena opittujen elintapojen tiedetään usein jatkuvan aikuisuuteen saakka, ja perheenperustamisvaiheessa elintavat siirretään taas seuraaville sukupolville. Lapselle tärkeitä ruokaympäristön tekijöitä ovat erityisesti koti, vanhemmat ja muut läheiset aikuiset, mutta myös päiväkoti- ja kouluympäristöllä on oma merkityksensä.

Ruokaympäristön mittaaminen on haasteellista, mutta siitä huolimatta sen yhteyttä lasten ruoankäyttöön on tutkittu jo jonkin verran. Kodin ruokaympäristö jaetaan usein kahteen ulottuvuuteen: sosiaaliseen ja fyysiseen. Käsittelen tässä ensin sosiaalista ruokaympäristöä, jonka käytetyimpiä mittareita on vanhempien ruoankäyttö. Vanhemmat nimittäin toimivat - sekä hyvässä että pahassa - roolimallina lapsilleen kaikissa ruokaan liittyvissä tilanteissa. On kohtuullisen paljon näyttöä siitä, että mitä enemmän vanhemmat käyttävät kasviksia ja hedelmiä, sitä useammin lapsikin niitä käyttää. Valitettavasti tutkimukset ovat kuitenkin usein keskittyneet tarkastelemaan vain yhden ruokaryhmän, kuten edellä mainittujen kasvisten ja hedelmien, käyttöä, vaikka ne ovat vain yksi osa ruokavalion kokonaisuutta. Toinen huomionarvoinen seikka on, että tarkasteltaessa vanhemman ja lapsen ruokavalion samankaltaisuutta vanhemmalla viitataan usein äitiin. Vaikka äidit yhä edelleen kantavatkin suuremman vastuun lapsen ruokahuollosta, isien rooli perheissä on jo muuttunut ja jatkaa muuttumistaan, eikä isiä voida enää jättää näkymättömän vanhemman rooliin.

Fyysisen ruokaympäristön mittarina käytetään usein eri ruokien saatavuutta kotona: siis sitä, kuinka usein kotona on esimerkiksi kasviksia, hedelmiä, virvoitusjuomia tai makeisia. Aiemman tutkimuksen perusteella näyttäisi siltä, että mitä useammin tai enemmän kotona on esimerkiksi kasviksia ja hedelmiä, sitä useammin lapsi syö niitä. Toistaiseksi suurin osa tutkimuksista on kuitenkin kuvannut kodin fyysistä ruokaympäristöä kovin yksiulotteisesti: joko terveellisenä tai epäterveellisenä. Todellisuudessa useimmissa kodeissa on yhtä aikaa saatavilla sekä terveellisiä että epäterveellisiä elintarvikkeita, eikä vain toisen ulottuvuuden mittaaminen riitä kuvaamaan kokonaisuutta.

Selvitin väitöskirjassani sosiaalisen ja fyysisen ruokaympäristön yhteyttä lasten ruokavalioon. Yhdessä osatyössä tutkin vanhemman ja lapsen ruoankäytön samankaltaisuutta sekä siihen liittyviä tekijöitä. Eräs mielenkiintoinen havainto tässä tutkimuksessa oli niin sanotun "sijaisraportoijan" vaikutus: lapsen ruoankäyttö muistutti enemmän sen vanhemman ruoankäyttöä, joka oli raportoinut lapsen ruokavalion tämän puolesta. Osatyön tulokset eivät siis tukeneet aiempia tutkimuksia, joiden mukaan lapsen ruokavalio muistuttaisi enemmän äidin kuin isän ruokavaliota. Siksi jatkossa myös isät tulisikin ottaa aktiivisemmin huomioon perheiden ruoankäyttöä tutkittaessa. Olen vakuuttunut siitä, että myös isät ovat kiinnostuneita lastensa hyvinvoinnista, ja tätä kannattaisi hyödyntää terveydenedistämiskampanjoissa. Suomen kaltaisessa tasa-arvoa vaalivassa yhteiskunnassa isiä ei tulisi enää vuonna 2018 kohdella B-luokan vanhempina.

Kahdessa muussa osatyössä tutkin kodin ja koulun fyysisen ruokaympäristön, siis ruoan saatavuuden eli ruoka- 
sisustuksen, yhteyttä lasten ruokavalioon. Jännittävää oli, että erityisesti epäterveellinen ruokasisustus kotona vaikutti olevan yhteydessä sekä päiväkoti- että kouluikäisten lasten epäterveelliseen ruokavalioon. Jos sekä terveellisiä että epäterveellisiä ruokia oli runsaasti saatavilla, epäterveellisillä ruoilla vaikutti olevan suurempi merkitys. Tutkimuksen perusteella voidaan siis suositella epäterveellisten ruokien saatavuuden rajoittamista kotona. Haluan kuitenkin korostaa, että rajoittamisella en tässä yhteydessä tarkoita sitä, etteikö epäterveellisiä elintarvikkeita, kuten makeisia tai virvoitusjuomia, saisi hankkia kotiin lainkaan. Liian tiukka rajoittaminen voi nimittäin vaikeuttaa terveen ruokasuhteen kehittymistä ja jopa lisätä "kielletyn hedelmän" houkutusta. Sen sijaan kodin ruokasisustuksessa kannattaa panostaa esimerkiksi värikkäisiin kasviksiin, hedelmiin ja marjoihin.

Viimeistään tässä vaiheessa on syytä kiinnittää huomiota siihen, että tosielämässä sosiaalista ja fyysistä ruokaympäristöä on mahdoton eristää toisistaan, ja syy-seuraussuhteen hahmottaminen on usein haasteellista. Vanhempien mieltymykset, asenteet ja tietämys vaikuttavat siihen, mitä ruokia he hankkivat kotiin. Kotona taas syödään ruokia, joita sinne on hankittu. Mutta tämä ei ole koko totuus. Vanhemmat nimittäin pyrkivät myös miellyttämään lapsiaan. On helpompi ostaa kotiin ruokaa, jonka tietää kelpaavan lapselle. Usein lapset myös ovat vanhempien muka- na ruokakaupassa, ja jo päiväkoti-ikäisten lasten tiedetään esittävän pyyntöjä siitä, mitä ruokia kotiin hankitaan. Eikä liene yllätys, että nämä pyynnöt liittyvät useammin Frozen-muroihin tai nallekarkkeihin kuin parsakaaliin tai kaurapuuroon. Onkin siis perusteltua pohtia, ei ainoastaan sitä, kuinka paljon vanhemmat vaikuttavat lapsen ruoankäyttöön, vaan myös sitä, kuinka paljon lapsi vaikuttaa vanhempien ruoankäyttöön.

Tämä tutkimus korostaa kodin ruokaympäristön merkitystä lapsen ruokavaliolle. Olemme luultavasti kaikki yhtä mieltä siitä, että epäterveellisistä ruokailutottumuksista ei kuitenkaan, toisin kuin Martti J Mustakallio 60 vuotta sitten kirjoitti, voi syyttää rakastavia äitejä ja helliä aviovaimoja. Sen sijaan voimme kääntää katseemme kauemmas. Koti ei suinkaan ole ainoa paikka, jossa terveyttä edistetään, eikä lasten terveellisistä elintavoista huolehtimista voi jättää ainoastaan vanhempien harteille. Kaikilla perheillä ei ole yhtälaisia valmiuksia tehdä vastuullisia valintoja elintapojen suhteen. Vaikuttaakin siltä, että epäterveelliset elintavat kasaantuvat perheille, joiden sosioekonominen asema on heikko.

Äskettäin julkaistussa katsauksessa Darius Mozaffarian kollegoineen kiinnittää huomiota siihen, että sekä ravitsemustiede tieteenalana että ympäröivä yhteiskunta ovat muuttuneet merkittävästi vuosien saatossa. Ravitsemustieteessä fokus on siirtynyt aliravitsemuksesta, energian ja ravintoaineiden puutteesta, kokonaisruokava- lioon ja ruoan terveysvaikutuksiin. Aliravitsemukseen liittyviä väestötason ongelmia on ratkaistu pitkälti viranomaistoimien avulla, esimerkiksi tukemalla maataloutta ja rikastamalla elintarvikkeita. Jostain syystä nykyajan suurimman terveyshaasteen edessä poliitikot ja viranomaiset ovat kuitenkin aseettomia, ja kroonisia sairauksia pyritään ehkäisemään lähinnä yksilöä vastuullistamalla. Mozaffarian ja kumppanit suosittelevat viranomaistason toimia väestön ruokavalion laadun parantamiseksi. Heidän mukaansa tehokkaimpia keinoja ovat esimerkiksi taloudellinen ohjaus eli erilaisten verojen tai tukiaisten käyttö. Lisäksi he painottavat lapsiin ja nuoriin kohdistuvan mainonnan säätelyä: elintarvikemainokset näyttävät nimittäin vaikuttavan lasten ruokamieltymyksiin, eikä lapsilla ole edellytyksiä erottaa mainoksia muusta ohjelmavirrasta. Yhtenä vaikuttavimmista keinoista he nostavat esiin myös päiväkotien ja koulujen roolin ja peräänkuuluttavat ravitsemussuositusten käyttöä ruokapalvelujen ohjauksessa. Tässä kohtaa voimme siis olla ylpeitä suomalaisesta yhteiskunnasta, jossa lapsille päiväkodeissa ja kouluissa tarjottava ruoka on terveellistä. Uskallan väittää, että suomalainen päiväkotijärjestelmä ja peruskoulu toimivatkin terveyserojen tasaajina, ja nykyisenkaltaisen, laadukkaan ja ilmaisen päiväkoti- ja kouluruokailun ylläpito ja kehittäminen edistää erinomaisella tavalla terveyden tasa-arvoa. 


\section{KIRJALLISUUTTA}

Ahola-Launonen J. Onko ihminen vastuussa sairauksistaan? Lääkärilehti 2018;73:1480-1481.

Calloway EE, Ranjit N, Sweitzer SJ, ym. Exploratory cross-sectional study of factors associated with the healthfulness of parental responses to child food purchasing requests. Matern Child Health J 2016;20:1569-1577. doi: 10.1007/ s10995-016-1956-6 https://doi.org/10.1007/s10995016-1956-6

Campbell KJ, Crawford DA, Hesketh KD. Australian parents' views on their 5-6-year-old children's food choices. Health Promot Int 2007;22:11-18. doi: 10.1093/heapro/dal035 https://doi.org/10.1093/heapro/ dal035

Health and joy from food - meal recommendations for early childhood education and care. National Nutrition Council. 2018. Mozaffarian D, Angell SY, Lang $\mathrm{T}$, ym. Role of government policy in nutrition - barriers to and opportunities for healthier eating. BMJ 2018;361:k2426. doi: https:// doi.org/10.1136/bmj.k2426 https://doi.org/10.1136/bmj.k2426
Mustakallio MJ. 90 \%:ssa kaikista liikapainoisuustapauksista on syynä tietämättömyys. Kirjassa: Similä Y. (toim.) Kuta pitempi vyö - sitä lyhempi elämä: Ajattelemisen aihetta ja neuvoja liikapainoisille. Helsinki: Oy Weilin \& Göös Ab; 1960, 70-74.

Pearson N, Biddle SJH, Gorely T. Family correlates of fruit and vegetable consumption in children and adolescents: a systematic review. Public Health Nutr 2008;12:267-283. doi: 10.1017/ S1368980008002589 https://doi.org/10.1017/ S1368980008002589

Pitkänen V, Westinen J. Samat huolet, eri näkökulmat: Tutkimus suomalaisten asenteista ja identiteeteistä. Raportti 2. e2 ja Suomen Kulttuurirahasto. 2018.

Rasmussen M, Krølner R, Klepp K-I, ym. Determinants of fruit and vegetable consumption among children and adolescents: a review of the literature. Part I: quantitative studies. Int J Behav Nutr Phys Act 2006;3:22. doi: 10.1186/1479-5868-3-22 https://doi.org/10.1186/14795868-3-22
Vepsäläinen H, Mikkilä V, Erkkola M, ym. Association between home and school food environments and dietary patterns among 9-11-yearold children in 12 countries. Int J Obes Suppl 2015;5 (Suppl 2):S6673. doi: 10.1038/ijosup.2015.22 https://doi.org/10.1038/ ijosup.2015.22

Vepsäläinen H, Korkalo L, Mikkilä V, ym. Dietary patterns and their associations with home food availability among Finnish pre-school children: a crosssectional study. Public Health Nutr 2018;21:1232-1242. doi: 10.1017/ S1368980017003871

https://doi.org/10.1017/

S1368980017003871

Vepsäläinen H, Nevalainen J, Fogelholm M, ym. Like parent, like child? Dietary resemblance in families. Int J Behav Nutr Phys Act 2018;15:62. doi: https://doi. org/10.1186/s12966-018-0693-1

HENNA VEPSÄLÄINEN

Helsingin yliopisto

Elintarvike- ja

ravitsemustieteiden osasto 